\title{
Effect of Capital Structures on Firm Value with Sales Growth and Return on Sales as Control Variables in Consumer Goods Companies
}

\author{
Zaenal Abidin $^{1 *}$; Rizki Reinaldy Putra²; Mahelan Prabantarikso ${ }^{3}$ \\ ${ }^{1-3}$ Management Program, Faculty of Economy and Business, Perbanas Institute \\ Jln. Perbanas, Karet Kuningan Setiabudi, Jakarta 12940, Indonesia \\ 1'zaenal@perbanas.id; ${ }^{2}$ rizkireinaldy@gmail.com; ${ }^{3}$ pmahelan@yahoo.com
}

Received: $28^{\text {th }}$ September 2020/ Revised: $8^{\text {th }}$ March 2021/ Accepted: $31^{\text {st }}$ July 2021

How to Cite: Abidin, Z., Putra, R. R., \& Prabantarikso, M. (2021). Effect of Capital Structures on Firm Value with Sales Growth and Return on Sales as Control Variables in Consumer Goods Companies. Binus Business Review, 12(3), $225-230$. https://doi.org/10.21512/bbr.v12i3.6724

\begin{abstract}
One of the attempts taken by the management to maximize the value of the company to compete with its rivals is decision-making related to capital structure strategy. The research sought to determine the effect of Short-Term Debt (STD) on Total Assets (TA), Long-Term Debt (LTD) to Total Assets (TA), and Total Debt (TD) to Total Assets (TA) on firm value by using return on sales and revenue growth as control variables. The research was a correlation research to observe the relationship between one variable and various other variables. The sample was consumer goods companies, especially food and beverage sub-sector manufacturing companies listed on the Indonesia Stock Exchange from 2015 to 2018. With a purposive sampling technique, there were 15 companies out of a total of 27 companies that met the criteria. Data were obtained from the Indonesia Stock Exchange website in the form of financial reports and closing prices. Then, structural equation modeling was used to analyze the data. Based on the analysis, there are several results. First, STD to TA and LTD to TA have a negative and significant impact on firm value. Second, TB to TA has a negative but insignificant impact on firm value. Third, sales growth has a positive and negligible effect. Last, return on sales has a negative and substantial effect.
\end{abstract}

Keywords: capital structures, firm value, sales growth, return on sales, consumer goods companies, Indonesia Stock Exchange

\section{INTRODUCTION}

The capital structure is a mix of debt and equity to fund the company's operations. The debt-to-equity ratio of a company affects the capital expense and value of the company. To maximize shareholder wealth, management in the company uses more debt in the capital structure because the paid interest can reduce the effective cost of debt and become a tax deduction. As a response, management must assess the debt and equity mix to maximize the company's market value. It is essential to identify the capital structure, the right size of the debt, and the capital that is best for the company (Abeywardhana, 2017).
Company value can be achieved if the company is supported by funding sources in the form of strong capital (Cahyanto, Darminto, \& Topowijono, 2014). A strong capital structure will assist the company in its operating activities as well as in investment activities. It allows the company to find sources of financing from internal and external sources. Internal funding may be obtained from owners/shareholders, and earnings may be retained. Meanwhile, external debt financing may be provided to creditors.

One of the attempts taken by the management to maximize the value of the company to compete with its rivals is decision-making related to capital structure strategy. The capital structure of a company is made 
up of a mix of equity and debt. Internal financing is provided in the form of equity, and external financing is provided in the form of debt (Mudany, Letting, \& Gituro, 2020).

Companies must find cost-effective funding solutions to satisfy their debt financing needs. Debt is an external funding source for the company (Zainudin, Ibrahim, Said, \& Hussain, 2017). Depending on the length of the debt, it can be divided into two types: Short-Term Debt (STD) and Long-Term Debt (LTD). The debt can benefit tax savings. The obtained interest expense is used as a deduction from income so that the profit before tax becomes smaller, and the impact on imposed taxes is also small. However, if the funding used by the company comes from equity, no interest expense can be used as a deduction from corporate taxes.

The value of a business is currently measured using a variety of economic measures. Based on $\mathrm{Fu}$, Singhal, and Parkash (2016), the Tobin Q ratio is used to measure the value of the company. Tobin's $Q$ is a metric that can be used to assess a company's worth. Tobin's Q is an investment-based indicator of business success that has been evaluated for top management in several circumstances. In 1969, James Tobin implemented Tobin's Q for the first time. It is also a metric to assess a company's success, specifically its value, demonstrating the management's ability to control its assets (Abata, Migiro, Akande, \& Layton, 2017; Ibrahim, 2017). A positive and important relationship is seen between Total Debt (TD) and Tobin's Q (Cahyanto et al., 2014). Meanwhile, according to Le and Phan (2017), there is a negative and essential relationship between TD and Tobin's Q-calculated company value.

There have been several debates about the relationship between capital structure and firm value, and much empirical evidence has led to several different conclusions. The value of Tobin's Q has been demonstrated by $\mathrm{Li}$ and Islam (2019). The research findings indicate that businesses are more leveraged if they operate in industries with stronger market efficiency. Moreover, there is a strong negative association between capital structure and company efficiency (Nassar, 2016). Meanwhile, according to Vuong, Vu, and Mitra (2017), on company efficiency as calculated by Earnings per Share (EPS), the EPS has no association with company leverage, but Tobin's $\mathrm{Q}$ does. Then, a negative relationship and a significant effect are identified on Tobin's Q through panel data analysis tools in all capital structure variables like STD to TA, LTD to TA, and TD to TA (Le \& Phan, 2017).

The decision-making of STD on companies considers the benefits and losses associated with the use. The company's management assumes that such decisions are based on special circumstances faced by the company. Taking STD will depend on the flexibility and financial strength of the company and the differences between short-term and long-term interest rates (Akingunola, Olawale, \& Olaniyan,
2018). Then, according to Prempeh, Nsiah Asare, \& Sekyere (2016), in capital structure analysis of firm value, there is a negative and important relationship between STD and TA and Tobin Q. So, the first hypothesis is that there is an impact of STD to TA on firm value.

The previous research uses Tobin's Q to reflect firm value (Chaleeda, Islam, Ahmad, \& Ghazalat, 2019). STD to TA and LTD to TA are two metrics used to determine corporate finance. STD to TA and LTD to TA have a favorable and meaningful relationship with firm value, according to the findings of Baseri and Hakaki (2018) in how financial and operating leverage and venture capital affect Tobin's Q. The venture capital and operating leverage positively correlate with Tobin's Q, while financial leverage has a negative relationship. The combined financial and venture capital have a negative correlation with Tobin's Q. However, operating leverage and venture capital have a favorable correlation with Tobin's Q. The second hypothesis is the effect of LTD to TA on firm value.

For the influence of TD to TA on Tobin's $\mathrm{Q}$, there is a relationship between debt financing and company performance on the Pakistan Stock Exchange. It shows that debt financing has a negative and significant effect on company performance. It recommends that companies rely more on internal financial sources because they are cheap and reliable (Aziz \& Abbas, 2019). However, according to Ahmad, Bakar, and Islam (2020), there is a significant and positive TD effect on TA on firm value. It recommends using more debt to reduce agency costs of equity, decrease the problem of information asymmetry, and improve investors' confidence to boost firm value. Similarly, it is discovered that TD to TA has a positive and significant relationship with Tobin's $\mathrm{Q}$ by using data regression panel analysis (Cahyanto et al., 2014). Meanwhile, based on Ibhagui and Olokoyo (2018), all capital structure variables, including STD to TA, LTD to TA, and TD to TA, have a positive and substantial effect on Tobin's Q. Therefore, the third hypothesis is that there is an influence of TD to TA on firm value.

Return on sales is a financial ratio that measures how efficiently a company generates profits from sales revenue (Batchimeg, 2017; Rouf, 2018). It shows how much profit the company generates after paying production costs such as wages, raw materials, and others, but it does not include tax and interest payments. The company's management seeks to improve return on sales to increase profits earned by the company. According to Berzkalne and Zelgalve (2014), there is a relationship between return on sales and the level of corporate profits. The efforts to increase return on sales will affect firm profitability. It indicates that the return on sales has a relationship with the level of profits derived by the company. For the fourth hypothesis, it is proposed that there is an effect of return on sales on firm value.

Companies with increased sales growth can increase production capacity and new product 
development and acquire other companies. According to Handoo and Sharma (2014), companies with high cash flow volatility and high growth can reduce debt on the company's capital structure over a certain period. Growth factors can be measured through changes in the percentage of company assets. In the fifth hypothesis, the research proposes an influence of sales growth on firm value.

In consumer goods companies, especially food and beverage sub-sector manufacturing companies, several researchers conduct mixed research on the impact of the capital structure on firm value with growth and benefit on sales as control variables. This idea has prompted the researchers to investigate the impact of capital structure on firm value with growth and return on sales as control variables in food and beverage sub-sector manufacturing companies. The expected results can determine the effect of capital structures on firm value in consumer goods companies and the extent to which sales can be a control variable. Figure 1 shows the research framework.

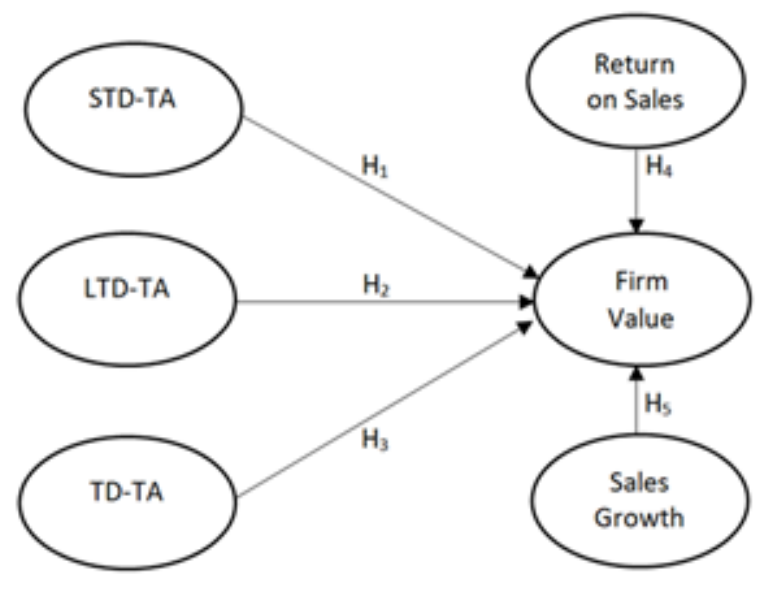

Figure 1 Research Framework

\section{METHODS}

The research is a correlation research to observe the relationship between one variable and various other variables. The sample for the research is the food and beverage sub-sector manufacturing companies listed on the Indonesia Stock Exchange from 2015 to 2018 . With a purposive sampling technique, 15 out of 27 companies meet the criteria for issuing financial statement data and complete stock prices from 2015 to 2018. Data are obtained from the Indonesia Stock Exchange website in the form of financial reports and closing prices.

SmartPLS version 3.0 is used to evaluate the structural equation models in the analysis. Multiple regression models and path analysis using observed variables can also benefit the Partial Least Square (PLS) approach (Ghozali \& Latan, 2015). Then, there are several tests conducted in the research. First, the coefficient of determination $\left(\mathrm{R}^{2}\right)$ determines the influence of all independent variables on the dependent variable. Second, the effect size $\left(\mathrm{f}^{2}\right)$ test is used to assess the magnitude of the predictor variable's influence on the structural model. Third, the Goodness of Fit (GOF) test determines an overall fit index for structural equation models. The overall research model is evaluated using GOF values. Last, the path coefficient analysis and the degree of importance are used in the discussion of hypotheses.

\section{RESULTS AND DISCUSSIONS}

The critical review of descriptive statistics shows mixed results for dependent and independent variables. Table 1 reports the summary of statistics for the variables in the research. Firm value measurement (Tobin's Q) shows a high-performance percentage on average. The average value for Tobin's Q is $64 \%$. However, capital structure measurements show a low percentage of performance. The average value of 0,24 for STD-TA is higher than the LTD-TA of 0,18 . Meanwhile, the average value for TD-TA is 0,42 . The observation data were 45 .

The test results show that the coefficient of determination $\left(\mathrm{R}^{2}\right)$ in structural equation models based on data processing results using SmartPLS version 3 are 0,73 . It implies that the variables in the analysis, such as STD to TA (STD-TA), LTD to TA (LTD-TA), and TD to TA (TD-TA), affect $73,0 \%$ firm value. The remaining $(27 \%)$ is from variables that are not examined in the research. Table 2 shows the result.

In the effect size $\left(\mathrm{f}^{2}\right)$ test, if it produces values of $0,02,0,15$, and 0,35 , it means that the predictor variable has a low, moderate, and high influence on the structural model, respectively. The test results for the effect size $\left(\mathrm{f}^{2}\right)$ in the research have a value of 0,28 for the STD-TA. It means that the STD-TA has a moderate effect on the structural model. Then, the value of LTD-TA is 0,14 , implying a low influence on the structural models. For the TD-TA, the value is 0,02 . It means that TD-TA has a low influence on the structural model. However, return on sales show a high influence on the structural model with the value of 1,61 . Then, the value of sales growth is 0,03 . It means a low influence on the structural model. The results can be seen in Table 2 .

The GOF test calculates the overall fit index in the structural equation model. The GOF values evaluate the measurements in the overall model used in the research. The value of 0,10 implies that the evaluation of the overall test model measurement has a low value. Then, the GOF value of 0,25 indicates that the overall research model produces a moderate performance. Meanwhile, the overall research model shows a high value when the GOF value is 0,36 . The estimation of the overall fit index of the structural equation model is determined using the GOF test with a value of 0,85 . It provides an assessment measurement of the impact of all independent variables. STD and LTD with the control variable of return on sales and sales growth have a strong influence on the dependent variable, 
Table 1 Descriptive Statistics

\begin{tabular}{lcccccc}
\hline & Firm Value & STD-TA & LTD-TA & TD-TA & Sales Growth & ROS \\
\hline Mean & 35,58 & 0,24 & 0,18 & 0,42 & 0,76 & 0,04 \\
Median & 18,46 & 0,23 & 0,16 & 0,47 & 0,06 & 0,07 \\
Maximum & 354 & 0,47 & 0,48 & 0,71 & 32,28 & 0,49 \\
Minimum & 0,74 & 0,07 & 0,01 & 0,08 & $-0,75$ & $-0,95$ \\
Std. Dev. & 70,07 & 0,10 & 0,13 & 0,17 & 4,81 & 0,25 \\
Observations & 45 & 45 & 45 & 45 & 45 & 45 \\
\hline
\end{tabular}

Table 2 Evaluation of Research Model Measurement

\begin{tabular}{lccc}
\hline Variable & $\begin{array}{c}\text { Coefficient of } \\
\text { Determination }\left(\mathbf{R}^{2}\right)\end{array}$ & Effect Size (f $\left.\mathbf{f}^{2}\right)$ & $\begin{array}{c}\text { Goodness of Fit } \\
(\mathbf{G O F})\end{array}$ \\
\hline Firm Value & 0,73 & & 0,85 \\
STD-TA & & 0,28 & \\
LTD-TA & & 0,14 & \\
TD-TA & & 0,02 & \\
Return on Sales & 1,61 & \\
Sales Growth & & 0,03 & \\
\hline
\end{tabular}

Table 3 The Results of Path Coefficients and Degree of Importance

\begin{tabular}{cccccc}
\hline Influence between Variables & $\begin{array}{c}\text { Original } \\
\text { Sample (O) }\end{array}$ & $\begin{array}{c}\text { Standard } \\
\text { Deviation }\end{array}$ & T-Statistics & Effect and Significance \\
\hline H1 & STD-TA $\rightarrow$ Firm Value & $-0,34$ & 0,14 & 2,45 & Negative and significant \\
H2 & LTD-TA $\rightarrow$ Firm Value & $-0,27$ & 0,15 & 1,81 & Negative and significant \\
H3 & TD-TA $\rightarrow$ Firm Value & $-0,11$ & 0,14 & 0,76 & Negative and insignificant \\
H4 & Return on Sales $\rightarrow$ Firm Value & $-0,67$ & 0,28 & 2,38 & Negative and significant \\
H5 & Sales Growth $\rightarrow$ Firm Value & 0,09 & 0,34 & 0,26 & Positive and insignificant \\
\hline
\end{tabular}

firm value. It suggests that the overall analysis model provides a high value for measurement evaluation. The test results GOF are shown in Table 2.

Table 3 shows the results of path coefficients and degree of importance. The results for path coefficients and the degree of importance between variables are obtained using an alpha value of $10 \%$ and a critical value of 1,645 . Moreover, path coefficient and significance level tests are used to see whether the independent variable impacts the dependent variable. Since the independent variables, such as STD to TA (STD-TA), LTD to TA (LTD-TA), and TD to TA (TD-TA) are $-0,34,-0,27$, and $-0,11$, respectively. The path coefficient test indicates that all independent variables have a negative effect on the dependent variable (firm value). The significance test indicates that the independent variables of STD to TA (STD-TA) and LTD to TA (LTD-TA) are 2,45 and 1,81 , respectively. Those values are greater than the critical value of 1,645 . Therefore, those hypotheses are accepted. Meanwhile, the value of TD to TA (TD-
TA) is 0,76 . It is less than the critical value of 1,645. So, the hypothesis is rejected.

Then, the return on sales as a control variable has a negative effect with a coefficient of $-0,67$, and sales growth has a positive effect with a coefficient of 0,089 . Moreover, the significance test shows that the return on sales has a value of 2,38 . It is greater than the critical value of 1,645 so that it accepted the hypothesis. Meanwhile, the sales growth has a value of 0,26 , which is smaller than the critical value of 1,645 . The hypothesis is rejected.

The hypothesis test results show a negative and significant impact on firm value for the STD to TA (STD-TA) measurement. These results are consistent with the research by Hasan, Ahsan, Rahaman, and Alam (2014). The companies tend to use debt to meet short-term financing needs, which may increase the profitability of the corporation through the received tax benefits. However, the company's management is still worried that the company has defaulted because STD has a relatively fast maturity. 
Next, the hypothesis test reveals a negative and significant effect on firm value for the LTD to TA (LTD-TA). The findings are in line with Baseri and Hakaki (2018). They found that the analysis of the combined variables of financial and venture capital had a negative association with Tobin's Q. Companies prefer debt over other alternatives, such as issuing shares to meet long-term funding needs. It happens because debt provides tax incentives that increase the company's value. LTD, on the other hand, is only a minor source of corporate finance.

Moreover, the hypothesis test indicates a negative impact on the TD to TA (TD-TA), but the effect on firm value is not significant. The findings are supported by Aziz and Abbas (2019), who found that debt funding had a negative impact on company performance, and the relationship between TD and firm value was negative and negligible. The company's management prefers to meet their funding needs through internal funding rather than debt. It can be caused by management trying to avoid debt costs and the risk of bankruptcy from the debt that can threaten the company's survival.

Similarly, the hypothesis result shows that return on sales as a control variable has a negative and significant effect on the firm value. However, the result is not consistent with Berzkalne and Zelgalve (2014). They found that the return on sales had a positive relationship with the amount of profit received by the business. Consumer goods companies, especially food and beverage sub-sector manufacturing companies, must pay careful attention to the optimum level of return on sales to ensure that the company's revenues are not affected.

\section{CONCLUSIONS}

Based on the research results, the value of the coefficient of determination $\left(\mathrm{R}^{2}\right)$ is 0,73 . It describes the massive effect of all independent variables. The food and beverage sub-sector manufacturing companies must pay attention to STD to TA (STDTA), LTD to TA (LTD-TA), and TD to TA (TD-TA), which have an immense influence on firm value.

Consumer goods companies, especially food and beverage sub-sector manufacturing companies, should accept both STD and LTD so that the portion of debt collection can be done by strategic decisionmaking to expand the market and maximize the value of the company. Companies also need to consider the optimal portion of the return on sales to support sales growth in the company's consumer goods products.

For the research limitation, the research does not take into account factors that can affect firm value, such as economic growth and macroeconomic indicators. So, future research can analyze economic growth and macroeconomic indicators on firm value. Moreover, future research can also use other financial indicators related to debt, such as Debt to Equity Ratio (DER) and Debt to Asset Ratio (DAR). The research can also use the infrastructure sector where, at present,
Indonesia is building many infrastructure projects in various places.

\section{REFERENCES}

Abata, M. A., Migiro, S. O., Akande, J. O., \& Layton, R. (2017). Does capital structure impact on the performance of South African listed firms? Acta Universitatis Danubius. Economica, 13(6), 334350.

Abeywardhana, D. Y. (2017). Capital structure theory: An overview. Accounting and Finance Research, 6(1), 133-138.

Ahmad, S. M., Bakar, R., \& Islam, M. A. (2020). The effect of debt financing on firm value: A panel data approach. Albukhary Social Business Journal, 1(2), 33-45.

Akingunola, R. O., Olawale, L. S., \& Olaniyan, J. D. (2018). Capital structure decision and firm performance: Evidence from non-financial firms in Nigeria. Acta Universitatis Danubius. Economica, 13(6), 351364.

Aziz, S., \& Abbas, U. (2019). Effect of debt financing on firm performance: A study on non-financial sector of Pakistan. Open Journal of Economics and Commerce, 2(1), 8-15.

Baseri, S., \& Hakaki, A. (2018). Analysis of financial leverage, operating leverage and capital venture effect on Tobin's Q ratio of investment and holding companies listed in Tehran Stock Exchange. Advances in Mathematical Finance and Applications, 3(1), 91-96.

Batchimeg, B. (2017). Financial performance determinants of organizations: The case of Mongolian companies. Journal of Competitiveness, 9(3), 22-33.

Berzkalne, I., \& Zelgalve, E. (2014). Return on equity and company characteristics: An empirical study of industries in Latvia. In The $8^{\text {th }}$ International Days of Statistics and Economics (pp. 94-103).

Cahyanto, S. A., Darminto, \& Topowijono. (2014). Pengaruh struktur modal dan profitabilitas terhadap nilai perusahaan (Studi pada perusahaan otomotif dan komponennya yang terdaftar di Bursa Efek Indonesia periode tahun 2010-2013). Jurnal Administrasi Bisnis (JAB), 11(1), 1-9.

Chaleeda, M., Islam, A., Ahmad, T. S. T., \& Ghazalat, A. N. M. (2019). The effects of corporate financing decisions on firm value in Bursa Malaysia. International Journal of Economics and Finance, 11(3), 127-135.

Fu, L., Singhal, R., \& Parkash, M. (2016). Tobin's Q ratio and firm performance. International Research Journal of Applied Finance, 7(4), 1-10.

Ghozali, I., \& Latan, H. (2015). Partial Least Square, concepts, techniques and applications using SmartPLS 3.0 program for empirical research. Semarang: UNDIP Publishing Agency.

Handoo, A., \& Sharma, K. (2014). A study on determinants of capital structure in India. IIMB Management Review, 26(3), 170-182. 
Hasan, M. B., Ahsan, A. M., Rahaman, M. A., \& Alam, M. N. (2014). Influence of capital structure on firm performance: Evidence from Bangladesh. International Journal of Business and Management, 9(5), 184-194.

Ibhagui, O. W., \& Olokoyo, F. O. (2018). Leverage and firm performance: New evidence on the role of firm size. The North American Journal of Economics and Finance, 45, 57-82.

Ibrahim, M. (2017). Capital structure and firm value in Nigerian listed manufacturing companies: An empirical investigation using Tobin's Q model. International Journal of Innovative Research in Social Sciences \& Strategic Management Techniques, 4(2), 112-125.

Le, T. P. V., \& Phan, T. B. N. (2017). Capital structure and firm performance: Empirical evidence from a small transition country. Research in International Business and Finance, 42, 710-726.

Li, L., \& Islam, S. Z. (2019). Firm and industry specific determinants of capital structure: Evidence from the Australian market. International Review of Economics \& Finance, 59, 425-437.
Mudany, J. O., Letting, N. K., \& Gituro, W. (2020). Effects of capital structure on performance: A critical review. Journal of Finance and Accounting, 4(3), 29-44.

Nassar, S. (2016). The impact of capital structure on Financial Performance of the firms: Evidence from Borsa Istanbul. Journal of Business \& Financial Affairs, 5(2), 1-4

Prempeh, K. B., Nsiah Asare, E., \& Sekyere, A. M. (2016). The effect of debt policy on firms' performance: Empirical evidence from listed manufacturing companies on the Ghana Stock Exchange. Munich Personal RePEc Archive.

Rouf, M. A. (2018). Corporate characteristics and leverage: Evidence from Bangladesh. PSU Research Review, 2(1), 96-104.

Vuong, N. B., Vu, T. T. Q., \& Mitra, P. (2017). Impact of capital structure on firm's financial performance: Evidence from United Kingdom. Journal of Finance \& Economics Research, 2(1), 16-29.

Zainudin, Z., Ibrahim, I., Said, R. M., \& Hussain, H. I. (2017). Debt and financial performance of REITs in Malaysia: A moderating effect of financial flexibility. Jurnal Pengurusan (UKM Journal of Management), 50, 3-12. 